\title{
The Morse Family Letters: A New Home in Iowa, 1856-1862
}

\author{
edited by Glenda Riley
}

The Morse family traces its ancestry back to a time when the American colonies had barely begun. In 1635 Samuel Morse uprooted his family from Sherburne in Shropshire, England, and replanted them in New England where in 1636 they became founding members of a wilderness town called Dedham in the Massachusetts Bay Colony. Here his progeny grew and prospered, as did the colony itself. Years later, after the War for Independence which transformed the English colonies into American states, Joseph Morse III purchased what was to become the Morse family homestead near Southbridge, Massachusetts.

Several succeeding generations of Morse descendants stayed in Massachusetts, but by the 1850s some of the younger members of the family were looking toward the new promised land, the American West, to fulfill their hopes and dreams. In 1856, Henry A. Morse, his wife Jane, his daughter Mercy Maria, and his son Herbert, moved to Iowa to become farmers near Genoa Bluffs in Iowa County. Henry's uncle, Lovell Morse, and Lovell's son, William, followed his lead, as did several other Morses during the next few years.

In the first section presented below are Henry's letters to his brother Francis and Francis's wife, Sarah, in Southbridge. Toiling as a shoemaker for inadequate wages, Francis wanted to 


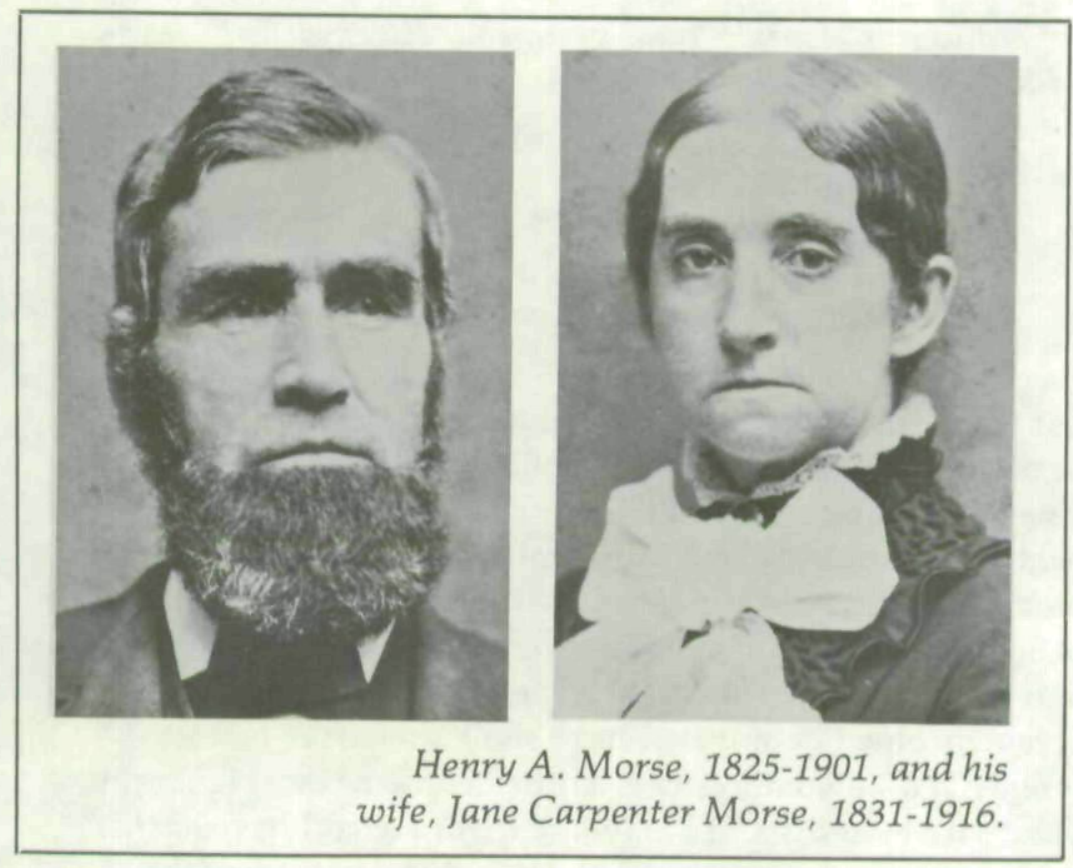

join Henry in lowa, but needed some advice and encouragement. As a result of Henry's reports and his supportiveness, Francis and Sarah joined their relatives in Genoa Bluffs in early 1858. Henry's brothers, Harvey and James, also migrated with their families, as eventually did his father, James B., his mother, Elvilia, and a young unmarried sister named Sarah.

The second section presented below are letters written by Francis and Sarah to Sarah's Aunt Eliza and to Sarah's sisters in Massachusetts. These letters also describe some of the hardships and disappointments which, by the 1860s, persuaded Francis and Sarah to turn their backs on Iowa and return to the East. The other Morses remained in Iowa, however, to live out their lives as westerners. James and Elvilia, Uncle Lovell, Henry and Jane, as well as many other Morses found their final resting place in the Genoa Bluffs cemetery.

The Morse letters have been abridged to delete sections dealing with purely family matters. The grammar, spelling, and punctuation have been changed occasionally to facilitate easier reading. The Morse letters appear here through the generous 
cooperation of Henry's great-grandson, Richard L. D. Morse, and his wife, Marjorie Johnson Morse, who live in Manhattan, Kansas.

Genoa Bluffs April 20/56

Dear Brother,

As we have no meeting to attend this afternoon and a week has passed since I have written, I will write a few lines. We are all well excepting colds. Herbert and Maria have had colds still cough a great deal. ${ }^{1}$ The weather most of the time has been cold and unpleasant, much finer today . . . . I attended meeting at the Schoolhouse last sabbath morning and listened to a very good discourse by an agent for a Methodist female seminary. Such preaching I do not expect we shall often have here at present. The stated minister is a little below the most ignorant of eastern Methodists "if I may judge from what I have heard." They have only one service. The rest of the day is spent (by many) in making calls etc. I hope things will be somewhat improved when a Sabbath School is formed. Measures have been taken to form one. Money has been raised, a Library and questions books sent for, and we shall meet to organize in a few weeks. All that are anything are Methodists here excepting our three families, ${ }^{2}$ several more families are coming in, also Methodists. As I said before I left S. [outhbridge] there will be nothing we shall feel the loss more than our Sabbath and weekly meetings. But although deprived for the present "and perhaps for a long time if we remain here" of the meetings of our choice, yet it is a cheering thought that we may "after our dwellings are erected" worship God at the family alter and at the social meeting without the noise and confusion usual here.

\footnotetext{
${ }^{1}$ Herbert, three years old, and Mercy Maria, five years old, were Henry and Jane's children when they moved to Iowa. Four more children were born in Iowa.

${ }^{2}$ The three families mentioned were Henry and Jane; Uncle Lovell and his wife, Clarissa; Lovell and Clarissa's son, William, and his wife, Susan; and several minor children.
} 
There is no meeting other than Methodist within 10 or 12 miles of us .... I will write no more today as I expect to go to I. [owa] City tomorrow to find a team and see about my goods. And shall have an opportunity tomorrow eve while there to fill out this sheet.

\section{Apr 21 Iowa City}

I have but a few moments this eve to write. Had an opportunity to ride to the City today. Arrived about 5 o'clock. Went to the Depot. My goods have not come yet. They were in Rock Island the 12 and as the bridge was to be completed so the cars could cross Monday 16 they thought best to wait as it would save loading once. But I have learned since coming here that they crossed today for the first time so perhaps they may come soon. I have had no time to look for teams today. Shall try tomorrow. Uncle L. [ovell] has bought one horse. He and Wm. are both here to procure more teams. I have cut some timber for a shanty but cannot haul it without a team. ${ }^{3} \mathrm{It}$ is almost impossible to hire one. I hope my things will come soon for I shall need my tools. The weather is chilly today, cold east wind. I think it must come off some snow banks there in the old bay state ... . .

\section{Your Affectionate Brother H. A. Morse}

\section{Genoa Bluffs May 5th/57}

\section{Dear Brother}

Your long and expected letter arrived the last day of Apr. and I will commence a reply as I expect to have to do it by piece meal unless we happen to have a rainy day which has not been the case since Feb. The weather has been very pleasant since the 20th of Apr. I have sowed 71/4 Acres of wheat which is coming up and for several days have been plowing my corn ground. It is so hard I cannot plow only part of a day at a time, had 11

${ }^{3}$ Henry and Jane's son, Herbert Carpenter Morse, died at age ninety-nine in 1952. He occasionally said that one of his earliest memories of Morses' Iowa home was of his mother holding an umbrella over him and his sister. He explained that the rain came through the roof of their farm home because it had been built with green timber which shrank as it aged. 
acres got half plowed. Have bought 50 apple trees and set them out 3 and 4 years growth from the grafting, paid 15 cents apiece, 18 different varieties. We are all well as usual excepting, Myself and the children have the worst colds we have had since we came here not very bad at that. I have done but little towards building fence yet. In many places the frost is not out. There have been a great many cattle and horses starved to death in Iowa this spring. I am almost the only one that has any hay. I have sold $1 \frac{1 / 4}{4}$ tons at 7 . per ton. Corn is 1.00 per Bush. where it can be bought. Very scarce. Wheat .75 many have fed that to the stock. I wish you were here to help me about planting. It will be quite a job. It did not get well retted. It is best to sow the first year and plant on old ground.

As regards your coming west I hardly know what to say, for I do not know what would be for your interest. And yet perhaps I can give you some information that will enable you to come to a decision. If I understand you aright, you have an inclination to come west and settle if you can do so and make yourself comfortable without getting into debt. As regards your news according to your statement of the expense of living in $\mathrm{S}$. [outhbridge] in a few years it will be less than now while at the same time it will cost more to purchase here. You say perhaps you could buy 40 acres. That would be enough for a farm as much as you would want to carry on. That can be bought for 400 , and a little further out for 300 , I presume. But I must stop for tonight.

\section{8th}

It is Friday eve as I will try and finish this letter. We have had a very windy day. Almost too windy to work. As regards Buildings, fencing and breaking it is true it will take some money to do the whole but you must do a part at a time. In regard to a team I think from what I have seen that a yoke of Oxen excepting to make long trips would be better and cheaper than horses. Horses are rather risky property, so many die of cholic. One span would be enough for two farms. A yoke of good Oxen would cost from 125 to 150 . My house will cost me in money paid out when finished about 375 . According to the price of lumber this season I could put up one like it for 325, I 


\section{The Morse Family Letters}

think. If you are in want of a house on the Prairie I will exchange work with you. It will save paying out money. As to fencing \& breaking you can do that by degrees. You can buy 3 or 6 acres of timber for 75 or 100 and from it get enough for the frame of a house, firewood \& fencing for 40 acres. The sum total as I have estimated it is:

$\begin{array}{lllr}\text { Land } & 350 & \text { Waggon } & 80 \\ \text { House } & 325 & \text { Timber } & 75 \\ \text { Oxen } & 125 & & 955\end{array}$

I do not know how much you have. But if you have not enough I would suggest that perhaps it would be better to borrow one or two hundred at $6 \mathrm{pr}$ cent of some one than to earn it at shoemaking at 60 pr year, that is, if you wish to come out here and settle with us. I would be very glad to have you here, but do not wish you to come unless it is best, perhaps you may get some light on the subject from what I have written, perhaps not. It is getting late and I must close . . . .

\section{Yours Affecly Brother H. A. Morse}

Genoa Bluffs Dec 18/57

\section{Dear Brother Francis}

I have been pondering upon the contents of your letter ever since I rec. it last Wednesday, and I am now hardly decided how to answer it. I wish you were here to see and understand the situation of the land and some other things. This piece of $\mathrm{Mr}$. B[enton] and one of Mr. Stover which I spoke of in my letter to Lucius ${ }^{4}$ I think (which it seems you had not rec. when you wrote) are the only pieces to be bought now very near me. Stover has come down from 15 to 10 dollars pr. acre for 80 of Prairie and 5 of timber, 850 for whole. How much more he will come down I do not know. He says he shall sell. I think at the price he now offers is as cheap as Bentons. It is improved around so that the first cost of fencing would be much less, joins me on the east, between me \& village. As regards land coming

${ }^{4}$ Lucius was another of the Morse brothers. There were ten children, seven male and three female. 
down it has already and there is no doubt but that it will be still lower. There are but few if any in this vicinity that will be obliged to sell to pay debts. But as it is the case in many other places it will have an effect on the price of land here. Besides I learned yesterday that an effort is making to have the School Land appraised and brought into market next spring for actual settlers . . . . I think These considerations and some others which I will not stop to name induce me to say to you that if you have not already collected the money, you had better hold on awhile, but of one thing I am confident that, people coming west next year and perhaps the year after can commence much cheaper than those who have come within a few years past. Land will be cheaper, so will provisions and Stock. Teams and Lumber .....

We have had quite warm weather since Thanksgiving. The ground had frozen nearly a foot in depth before that, now it is nearly out. James says he thinks Harvey will come in Feb. if he can get money that will pass in Iowa. He can get a certificate of deposit for which he can get current bills at Cook, Sargeant, \& Downey. And if he lost it on the way he could get another. It seems from your letters that each of you expected the other would write the news. And so I got but a small share. Shall expect the more next time. I have written to Father \& Mother to come out here another season. If you do not come yourself or if you do, do what you can to help them off. Sarah will not always be at home to do the work. ${ }^{5}$ I feel that if they fail of coming another season they may not come at all. Jane was intending to write to Sarah this time but she is busy taking care of meat and my envelope is full. Killed one hog this week.

\section{H. A. Morse}

\section{Genoa Bluffs Jan. 1858}

Dear Brother Francis

... I have today made proposals to $\mathrm{Mr}$. Stover in regard to his 80 . I offered him 10 dollars for it and 10 acres of good

\footnotetext{
${ }^{5}$ Sarah was second youngest of the ten Morse children. She migrated with her parents to Iowa, but never married. She died at age twenty-six in 1866, the same year that her father died.
} 
timber with it, 90 acres for you. He gave me the refusal of it till I heard from you. It is a good 80 lays between me and the village, joins me on the west, Harvey on the South. I consider this better than to pay Benton 8 for those reasons. It will be less work to fence as it is or will be soon improved around it by those having help. The first cost will be less, another reason is you get timber with it. Timber is worth 20 to 25 per Acre. Calling it 20 it would leave the Prairie 8.75. It lays nearer the City of Genoa consequently is more saleable and valuable. It also joins me and I have the vanity to think that it is worth more on that account especially to you .... There is but little difference between the two 40 as regards the quality of land, the north 40 is opposite to one on which my house stands. And would therefor be nearer me. I should rather for that reason you would have it. On the N.E. part of it there is a good place for a meeting house. And if you take it I want you give us land enough to put one on. We are talking pretty strongly of building one another season.

I would not advise you or anyone else to buy land to speculate upon. This I have written before. I have therefore constructed that you intend to come west sometime or you would have told me before this to stop bantering for land. If Harvey is with you he can tell you about this location of the land. Perhaps it could be bought cheaper next summer but I doubt it owing to its location near the village .... I think a person who can dispose of his property to advantage can come west and commence cheaper next season than any other time for a number of years, because probably things will rise as times improve, perhaps I am mistaken. I do not know but this comprises all the business matter necessary now .... .

\section{H. A. Morse}

II

Genoa Bluffs Aug 11/58

Dear Aunt Eliza

.... I do hope the time may come, that we may enjoye better Religious privaleges. I trust we might prize them more 
than ever before from having been deprived of them, the Cong. Church established here numbers but 8 members. Sister Susan wrote you were making them a visit. I was very glad to hear it. But you will want to here what We are doing. I wrote you in my last letter about F's [Francis] going to the city \& the next week he worked for Uncle Lovell, Henry, \& a neighbor cutting Wheat \& Oats, the next week Henry, \& he went to the City to get another load of of boards Window frames etc. . . . I can hardly tell you how anxious we are to get into it. ${ }^{6} \mathrm{We}$ think now we shall go into it as soon as we get it up and covered, lath, \& plaster it afterwards. Shall not probably clapboard or paint it at present or dig a well this year, briny water from here to drink \& dig a slue well to get water to wash with. There is a house full of us now \& if Brother James \& his family should be here by the 1 of Nov-it would be running over. F. [rancis] had our cellar dug and also a drain. Underpining of brick laid \& for a day or 2 I have been plaining boards. Today and tomorrow thrashing wheat \& oats. We hope the time will then be devoted to the house \& that we may be favored with good weather, for the last 2 or 3 weeks the weather has been exceedingly hot. We have suffered very much with Musquitos. I think we never knew what it was to be troubled before this summer. We think it rather hard to be obliged to work hard days \& not sleep much nights. Hope we shall have cooler weather before long \& get rid of them.

I think every thing considered we have been pretty well. I find it quite hard to do my work here. It tires me to have to go up \& down stairs so much. I find it rather hard work to be patient some times. Every thing seems so different here but if we are to make it our home I hope I may be contented. I will not say there has been no home sickness ... . As for me tho I try hard to drive the bad feelings off they will come on sometimes, \& were it not that I hope it will be better for Francis on some accounts bye \& bye I could wish I had never seen Iowa. I can not tell you how much I miss you all. We have scarcely any society here, I have not got acquainted with any of the neighbors yet ...

\footnotetext{
${ }^{6}$ Sarah's reference was to the house Henry was helping Francis build for Francis and Sarah.
} 
perhaps I shall yet be very happy \& glad we came, you must not be anxious about me . . . . From your aff. Niece Sarah

\section{Genoa Bluffs Monday Sept 6th 1858}

My very dear Aunt Eliza,

I think of you all a great deal. Our little Walter is very well, grows very fast this summer. ${ }^{7}$ We think the climate \& the milk he drinks agrees with him. Francis is pretty well though has some cold \& is some troubled with head acke. It is thought however that people in this part of the country are more free from colds, than at the east, and my own experience \& observation leads me to think that the state of health is better at least about here. I have heard of but very little sickness since we have been here. My own health is very good except that I am some troubled with teethacke. The rest of our friends here are all well at present. I must tell you that the eye stone you gave me was made use of for the first time last Saturday. F. [rancis] got some saw dust into his eye which was very painful until the stone removed it. We shall no doubt find it very useful.

As Francis is going to help me write the letter, I will leave some of the questions proposed in your letter. And first accept our sincere thanks for your kind offer. We know that money is hard to get \& we both feel that you ought not to think of sending any. We are very sensible. You have done a great deal for us. Far too much for your own interests. When you first wrote of sending a few things by Brother James \& wished me to specify what I should like to have provided if I were to purchase, I did not dream of doing any such thing as I felt you ought not to spend any more of your money for me. But as you have made mention of some articles, I will say what I think would be useful. Francis has never worn flannel under shirts but says he thinks perhaps he would find them acceptable here, the winters are more than severe here on account of the strong winds. I do not know how much it would take. I should not think more than $2 \mathrm{yds}$ for 1 shirt. I was intending to make

\footnotetext{
${ }^{7}$ Walter was Francis and Sarah's son, but since there is little information extant on their part of the family line, Walter's age is unknown as well as that of any other children Sarah bore.
} 
winter dresses for Walter cut out of the strips of calico, Mother gave me. But I know flannel or deleine would be warmer \& save some washing. If it was not very wide I suppose it would take about 2 yards for a dress but do not get it if it is very high, as cheap deleine will answer. As for my own clothes I am very well provided for with ease I think my calico dresses will last nicely 2 years if I should live. I should like very much to have $3 \mathrm{yds}$ of yellow flannel for skirts. If I had a remnant of cheap deleine or other wollen material rather dark I would make it into a sack for every day wear next winter. They tell me so much about the extream cold weather, that it almost frightens me sometimes, but perhaps it will not be so cold next winter. I was sorry I did not get me a thick barage veil, mine is a very thin one. In regard to paper etc., I have enough to write you \& my other friends quite a number of letters yet though my stock was not very large. Brother Henry said he bought a ream before he came out here \& got it a great deal cheaper, his is not quite gone yet .... I do not know why soap should be so scarce here tho the Westerners do a great many things different from what we would. They waste their soap greese by giving it to the dogs \& pork is rather scarce. We have bought about $14 \mathrm{lbs}$. of pork \& 2 small hams since we have been here. Jane says they had not scarcely any meat all the first summer they came here \& went without butter all the next winter. The Dutch do not Salt their butter \& so have none to lay up for winter. They smoke their pork \& that gives it a very unpleasant taste. We shall be glad to fat \& kill our hog as soon as can we shall, need the meat. I would like a few whole cloves, they relieve teeth acke sometimes. In regard to soap it would not be best to send any as it would be bulky \& heavy. I have enjoyed 2 gallons of soft soap at 25 cts per gal. They ask Just double what they do in Southbridge. But I hope to make my soap myself sometime.

Perhaps you would like to know the price of some of the things at Iowa City. They have no store here at present, both stores were closed the next week after we came. Molasses $50 \mathrm{cts}$ per gal, sugar $9 \mathrm{lbs}$ for a $\$$, cream of tarter $50 \mathrm{cts} \mathrm{lb}$, best black tea 80 . Pins \& needles $10 \mathrm{cts}$ a paper, spices not much higher I believe than at the east, I made my first purchase in dry goods 
when F. [rancis] last went to the city, blue knitting cotton $10 \mathrm{cts}$ a skien, it is $4 \mathrm{cts}$ in S. [outhbridge]. I sent for 2 lemons to put into tomato preserves $5 \mathrm{cts}$ apiece, F. [rancis] said Apples were $5 \mathrm{cts}$ apiece. The fruit seems to be all cut off here, it is quite a disappointment to us. You dont know how glad I am I had some dried apple to bring out with me. I am very choice of it. I often wish I could get some of the lemon peal lying about on the sidewalk, but I try not to think of the luxuries I am deprived of any more than I can help. Perhaps we shall have more another year. We have a good garden with Henry. When we get things started we shall probably have more but for a while we must be content with a little \& with such as we can get. But I must hasten to close or F. [rancis] will have no room to write. Something to keep off the musquitos would certainly be very acceptable \& I thought I should like to have some frames fitted to the windows in our bed room \& Kitchen another summer ( 4 windows). The muslin that covers them is called musquito bars. It is very cheap stuff. I do not know whether they have it here or not, I should think colored would be better than white on acount of not showing dirt. And now my dear Aunt Eliza if you remember what you have written you will see that I have complied with your request, that my pen has gone rather slow over a part of this letter \& I feel rather unwilling to send such a beging letter as it would certainly sound to one to read it \& both F. [rancis] \& I think that if you should send any of the articles mentioned you ought not to ever think of sending any money. We would rather you would keep it towards coming out to make us a visit one of these days. I could write much more but ought to stop at once so with a great deal of love to you all I remain Your very aff \& much obliged Niece Sarah

\section{Genoa Bluffs Sept 7th 1858}

\section{Dear Aunt}

Sarah wishes me to write a few lines to you in this letter and as I have a little leasure this evening I will do so. I suppose you would like to know what I am doing and how I like western life after a six months trial. When we came here brother Henry proposed to me that we should exchange work so that we could 
work together and as I had no team I could use his and pay in work. He has one span of horses and one yoke of oxen. I thought it would be the best way to do as I had not money enough to buy a team besides what I should have to spend if I built a house, so that a part of the time I have worked for him and he has worked for me. We are now to work upon the house. We have got the frame up but have not got the roof on yet, hope to put that on tomorrow. We shall finish the lower part of the house as soon as possible so that we can move into it as we are rather crowded here. Henrys house is only 16 feet wide and 24 long with 2 rooms below and 3 above, 2 of them small. And there are 3 families in it, 10 of us in all besides all of our things, rather thick for hot weather but we hope to be better accomodated before a great while. You may think it strange that they do not build larger houses here but the reason is lumber is very scarce. I am obliged to go to the city about 40 miles for all my house except the frame which I got from my 5 acres of timber and it has cost me more than I expected owing to the wet season and bad roads.

In regard to living here I would say I did not come out here expecting to get rich so that I am not at all disappointed in that respect. I came here hoping that we might get a place that we could call home and if we are favored I think we shall succeed though we may get in debt some. I see by the papers that there is not much encouragement for poor people at the east, the cost of living increase while wages decrease. I would like to write more but have not time this evening and we have a chance to send this to the City tomorrow ....

yourself from Francis

\section{Genoa Bluffs Saturday Feb 261859}

\section{My Dear Aunt Eliza}

. . Henry's Wife has a daughter born Thursday Morning. ${ }^{8}$ It weighed $9 \mathrm{lbs}$. Jane was not sick but about an hour, is very comfortable. I have not seen her for a fortnight. James Wife

${ }^{8}$ The daughter born to Jane was named Mary. She was the third of their six children, but was the first of the six to be born in Iowa. 
was with her at the time, ${ }^{9}$ the doctor lives 5 miles off and did not get there untill a good while after it was over with. In regards to the question you asked in your letter you had a perfect right to do so, \& I will say that I think I can report similar news concerning myself before a great while, about the first of April. I have enjoyed excellent health with the exception of teeth acke which I have suffered with more or less for a great while \& was anxious to have several taken out but was advised not to, \& perhaps it was for the best after all as they have not troubled me for about a month. I do not think they will trouble me any more. We have all had bad colds since I wrote you last but have got nearly over them.

I suppose you will want to know how we get along in regard to living etc. I wish that I could write it was all sunshine but at present things look rather discouraging to us. Perhaps they will look brighter bye \& bye. It has been hard for us so far in many respects \& we are disappointed, as far as we can see it has prooved to have been an unfavorable year for us at the west, but I suppose you would say to us do not despond yet. We are very glad Father Morse is coming here. We received a letter from Sister Sarah yesterday making some inquiries in regard to the journey \& the prospect of a tenement here. They are to leave there farm the first of April \& if they can get a tenement will pack up their goods \& come here, if not will stay until fall. Henry wrote back to them yesterday, do not know what he wrote. I for one am very glad they have decided to come for if they were not it would seem as tho' I could not stay here any longer but I hope for Francis' sake it will be plesenter for us when they are here.

Francis thinks he will write you a little this evening so I will not write much more. You spoke of sending us some more mosquitoes bars. You sent enough for 6 windows \& it will be enough, for if we should ever have a shed or wood house I do not think we should need any to the door. As you asked about dried apple I will say that it is very high here \& not very good, that you sent us was beautiful \& we have some on hand now as I have been saving of it. It has been a very great help to us this

'James' wife's name was also Sarah. 
winter as we should not have had any if you had not sent it but Francis \& I both feel that you have been very generous to us already \& we ought not to ask for another thing. The peach preseve I have not opened yet as I thought it would keep \& we might want it more bye \& bye. If I could have a yard \& $1 / 2$ of red cambrick to line a sack for Walter I would like it. It is an old one that Mother gave me some time ago. They had a small store here a while ago but it was soon closed . . .

from your aff Sarah

\section{Genoa Bluffs April 27th 1859}

My Dear Aunt Eliza

....We are all pretty well excepting colds. I have not quite got rid of mine. F. [rancis] \& W. [alter] have some cold. The baby has appeared to have a bad cold in its head ever since he was a few days old. At times he has been very much troubled about breathing \& for the last 3 days has seemed to be in a good deal of pain with colic. He has not been out of my arms long at a time today still I get along pretty well tho' I find my hands full I assure you. It is fortunate I have got my sewing as well done as I have or I should be discouraged. Father M.[orse], \& his family arrived here a week ago to night. Harvey met them at the city. We did not see them that eve, but they all came over the next morning \& have all been here several times since. It seems very plesent to have them with us. Father and Mother think they stood the journey very well. Mother had quite a bad cold when she got here but is better .... Sarah is with Harveys wife. She is very feeble.

Father gave me the money you sent . . . . It does seem too bad for us to take it from you. I do not know what else we can say but to express our warmest thanks for it \& all the rest of the things you sent as tho' I am sure if I could have had a chance I should have refused part of them at least. We think you must mean we shall not suffer for the want of tea to drink. I have enough to last us a long time. Francis want to know if you have any more thread \& tape left, think I have enough to last a number of years. Francis says he wishes Aunt Eliza had kept her 
money towards paying her fare out here to make us a visit sometime.

Fathers goods arrived at the city a few days before they did. Henry had gone for them that week \& to get some other things for them to keep house with. They are intending to go to housekeeping as soon as the goods come. Francis has sown 3 acres of his land with wheat. It has come up \& looks well. He is now plowing $31 / 2$ acres to plant with corn \& potatoes ... .

From your aff Niece Sarah

\section{Home Sept 201862}

My very dear Sisters

.... I would gladly write you all a good long letter if I could command the time but if you knew just how I was situated feel that you would cheerfully excuse me this time \& I know you do not need such a proff of my love. My time is almost wholly occupied with my house work so I find little or no leisure for any thing else. I have not done any sewing scarcely this summer \& I have a good deal to do before cold weather. We are all pretty well at present though Francis seems most worn out with hard work. He has had a hard time this summer and gets little or no time rest of body or mind. Hope he will not always have to work so hard but farming is a hard life to lead. He finished threshing today. We had $156 \mathrm{bu}$. of wheat. Our chamber floors are covered with it. The market price is but $50 \mathrm{cts}$ per bu. We shall not sell any at present tho I dislike having my house so filled with it .... I remain your ever loving sister 
Copyright of Annals of Iowa is the property of State of Iowa, by \& through the State Historical Society of Iowa and its content may not be copied or emailed to multiple sites or posted to a listserv without the copyright holder's express written permission. However, users may print, download, or email articles for individual use. 